Western University

Scholarship@Western

Aboriginal Policy Research Consortium International (APRCi)

$1-12-2012$

\title{
Housework Metaphor for Gambling Public Health Action: An Indigenous Perspective
}

Lorna Dyall

Zoe Hawke

Ruth Herd

Papa Nahi

Follow this and additional works at: https://ir.lib.uwo.ca/aprci

Part of the Other Mental and Social Health Commons

Citation of this paper:

Dyall, Lorna; Hawke, Zoe; Herd, Ruth; and Nahi, Papa, "Housework Metaphor for Gambling Public Health Action: An Indigenous Perspective" (2012). Aboriginal Policy Research Consortium International (APRCi). 239.

https://ir.lib.uwo.ca/aprci/239 


\title{
Housework Metaphor for Gambling Public Health Action: An Indigenous Perspective
}

\author{
Lorna Dyall • Zoe Hawke • Ruth Herd • Papa Nahi
}

(C) Springer Science+Business Media, LLC 2012

\begin{abstract}
Housework, those duties done at home or in one's community to keep and clean and tidy, is used in this paper as a metaphor for Māori involvement in gambling public health action in New Zealand. For over a decade Māori have been developing their own voice, public health actions, gambling services, research and workforce development initiatives to address gambling related harm at a whānau, community, local government, national and now international level. Involvement in gambling public health action has required Māori to utilise our Treaty of Waitangi and now international indigenous peoples' rights to ensuring legislation and host responsibility requirements are met at all levels in New Zealand society. Housework which is a demanding task required to be done on a regular basis Māori have found never ends. To address this situation Māori have moved their focus to those organisations which have duty of care responsibilities defined under the Gambling Act 2003 and local government responsbilities to involve them in housework duties. By working together, Māori have assumed this will assist in reducing gambling related harm. Efforts made by Māori have been shared at our first international indigenous gambling conference held in New Zealand to warn our local Pacific nation neighbours of the risks associated with expansion of gambling.
\end{abstract}

Keywords Māori · Gambling public health action · Indigenous rights · Duty of care responsibilities

\section{Dyall $(\bowtie)$}

Te Kupenga Hauora Māori, Auckland University, Auckland, New Zealand

e-mail: 1.dyall@auckland.ac.nz

\section{Z. Hawke}

Hapai Te Hauora Tapui Ltd, Māori Public Health, Auckland, New Zealand e-mail: zoe.hawke@hapai.co.nz

R. Herd

Gambling Research Centre, Auckland University of Technology, Private Bag 92006, Auckland 1142,

New Zealand

e-mail: ruth.herd@clear.net.nz

P. Nahi

Māori SIDS, School of Population Health, Auckland University, Private Bag 92019, Victoria Street West, Auckland 1142, New Zealand

e-mail: papa.nahi@auckland.ac.nz 


\section{E toro nei nga kawai, taura tangata}

The human links extend like branches of a tree

Commercialised gambling is increasingly becoming available in different parts of the Asian and Pacific region. When introduced into a country or community, there is often considerable discussion of the proposed benefits which will arise over time, often led by politicians, community leaders or those involved in the business of gambling. To smooth the pathway of gaining support for commercialised gambling such as the introduction of casinos, gambling machines, horse racing and sports betting and other forms of gambling as lotteries, the public is often informed that such developments will increase wealth. Further, there will be positive benefits for individuals, communities, the Government and local businesses. Casinos, for example are often promoted as businesses which create new local employment opportunities, provide adult entertainment, support local infrastructure and encourage tourism. Casinos act as a draw card to attract local and overseas visitors to spend their resources (Australian Institute for Gambling Research 1998; Dyall 2009). For gambling machines, it is proposed they will generate local wealth, as money lost or invested in these machines will provide new revenue for governments, provide funding for local community groups and will create new recreational and socialising opportunities. Horse, track and sport betting, is often promoted as a chance to pick winners, to beat the odds and to develop your own personal betting systems identifying which horse or animal is likely to win taking account of all known knowledge of the genetics of the animal, previous track record and jockey on the day. Horse racing is seen as a legitimate industry in New Zealand where animals are breed for their genetic ability to race.

Lotteries which may be state or locally organised are promoted as a means for individuals or groups to have the chance to win a significant sum of money and through this game of chance may be able to achieve their personal dreams, escape from boredom and to live a life of dreams (Dyall 2004). Promotion of gambling by way of advertising and availability supports individuals to day dream or live in a world of magical thinking. This is also used as a means of escaping poverty. Existing alongside commercialised gambling there is also often different forms of informal gambling which may be organised within families and communities, which may have cultural or whānau links such as mahjong, different card games, bingo or housie and local forms of raffles. Whilst the benefits of gambling are often promoted, those who have vested interests in their continuation, often down play the negative or public health costs involved.

Gambling and problem gambling is increasingly rising and becoming normalised in different communities in the Asian and Pacific region yet the real public health harm to the lives of individuals, families and communities is often not appreciated until the health, social, economic, justice and education costs becomes visible.

This paper, discusses the experience of Māori engagement in the business of addressing gambling harm in New Zealand and how often tangata whenua (people of the land) are contracted to do "housework" to help assist in tidying up messes that others have created, with little power or authority to change the dynamics or the business gambling in Aotearoa (New Zealand). The paper covers Māori national and international indigenous rights in relation to gambling and roles and responsibilities Māori have performed informally and formally to be involved in housework to help clean up messes which have occurred in our communities as a result of gambling. 


\section{Māori: Treaty of Waitangi and International Indigenous Rights}

Māori the indigenous population in New Zealand now have both Treaty of Waitangi rights and international indigenous human rights. Prior to the introduction of casinos and gambling machines Māori were identified as having two to three times the risk of problem gambling than nonMāori in New Zealand, (Abbott and Volberg 1991). With this information, Māori should have been identified as a key population group to be consulted and involved in the development and implementation of health and social interventions and the review of gambling policies to reduce gambling harm. Unfortunately, this did not occur and along with other introduced hazardous activities and substances in New Zealand, gambling along with tobacco and alcohol, now create many health issues for Māori at an individual, whānau, population and national level (Durie 2001). The paper draws upon the author's doctoral study investigating gambling as an emerging public health issue for Māori, and involvement in working with Māori at different levels to address gambling harm (Dyall and Hand 2003). During the course of this research, with the development of awareness of the harms associated with gambling, an independent Māori organisation called Te Herenga Waka o Te Ora Whānau (THWOTOW) was born.

The role of this organisation has been to articulate an iwi and indigenous view on the harms gambling creates for Māori and others in New Zealand, (Dyall 2010a, b). In 2010, THWOTOW organised its first Indigenous Problem Gambling Symposium in Rotorua, with the primary purpose to engage with other indigenous peoples' especially those from Pacific and Asian nations to share and discuss knowledge of the harm gambling creates over time in vulnerable indigenous families and communities. From this symposium, held in a significant Māori community, participants have concluded that problem gambling is like other forms of addictions it has wide effects and creates intergenerational trauma. This realisation is important for emerging and developing Asian and Pacific nations whom are often encouraged to become involved in commercialised gambling following the footsteps of western countries as Australia, New Zealand, England and states in Canada and United States of America.

The New Zealand Government has endorsed the United Nations Declaration on the Rights of Indigenous Peoples' (Human Rights Commission 2008). This decision is important for first nations and many indigenous populations who live in the Pacific region now have international indigenous human rights. The United Nations Declaration on the Rights of Indigenous Peoples' consists of 46 articles covering all aspects of indigenous peoples' lives, from the right to self determination and protection from governments to ensure that they survive and to being able to define and request the development of institutions, services and policies which promote their cultural, spiritual, economic and social wellbeing, defined on their own cultural terms.

Along side these rights, Māori have rights also defined in New Zealand's founding constitutional document the Treaty of Waitangi. This document gives Māori the right to shared governance of New Zealand as a nation. Further, that hapu and iwi (tribal) have the right to own and control their own resources, including treasures that they hold as important. Māori are also to be treated equally as British subjects in all areas of New Zealand life. Māori involved in gambling have used the Treaty of Waitangi as a framework for public health action, and have used this ongoing social contract as the context and basis of any discussion and housework activities to reduce gambling related harm in New Zealand, (Dyall 2002; Dyall and Morrison 2002) This decision is not radical as it was proposed with the introduction of casinos in New Zealand early 
in 1990s that they should develop further in the context of the Treaty of Waitangi, (Department of Internal Affairs 1996)

Since then Māori have argued for greater recognition of their Treaty of Waitangi rights in New Zealand and now claim their human rights defined in United Nations Declaration on the Rights of Indigenous Peoples (Dyall 2009). The following articles have been identified in a New Zealand setting, which are appropriate to consider for public health action to reducing gambling related harm for Māori. They are:

\section{Article 4}

"Indigenous peoples, in exercising their right of self determination have the right to autonomy or self- government in matters relating to their internal and local affairs, as well as ways and means for financing their autonomous functions"

\section{Article 5}

"Indigenous peoples have the right to maintain and strengthen their distinct political, legal, economic, social and cultural institutions, while remaining their right to participate fully, if they so choose, in the political, economic, social and cultural life of the State".

\section{Article 18}

"Indigenous people have the right to participate in decision- making in matters which would affect their rights, through representatives chosen by themselves in accordance with their own procedures as well as to maintain and develop their own indigenous decision- making institutions"

Article 23

Indigenous peoples have the right to determine and develop priorities and strategies for exercising their right to development. In particular, indigenous peoples have the right to be actively involved in developing and determining health, housing and other economic and social programmes affecting them and, as far as possible to administer such programs through their own institutions. (Human Rights Commission 2008)

These rights give Māori a legitimate role and a responsibility to sit on any board or committee where gambling is being discussed, such as interdepartmental policy committees, Cabinet and gambling distribution bodies which make decisions as to whom should receive financial benefits from losses from gamblers.

Māori engagement in the business of gambling should be treated no differently than other areas where resources are jointly owned between Māori and the Crown. In New Zealand, the Crown and iwi collectively own and govern fish stocks. On an annual basis, quota for specific fish species are allocated to different tribes based upon their ownership of coast line and traditional fishing rights. In view of this relationship, it provides a model for iwi and Māori groups to establish equal partnerships with the Crown in other areas of social and economic development.

Māori do not need to own their own casinos or gambling machine licences as other indigenous peoples. Instead Māori and iwi can now be accorded their Treaty of Waitangi and international indigenous rights and be given the right and responsibility to sit at different tables with Crown's representatives and be involved at all levels of decision making in determining gambling policies and directing where gambling revenue should be directed and whom should benefit at minimum from social and economic harm (Dyall 2010a, b) Involvement in such decisions would allow Māori along with other stakeholder interest groups to determine whether we want legalised gambling to continue and if so, on what scale. In addition, Māori alone or with others, would be able to negotiate and navigate the 
development of gambling free communities or neighbourhoods. Increasingly, it is being recognised internationally and in New Zealand, that the degree of social deprivation within neighbourhoods and communities, affects the health of those who live there, for they are exposed to different social hazards, such as the effects of alcohol abuse, problem gambling and criminal offending (Dyall 2006; Marmot 2010).

At present, Māori constitute at least a third or more of the population of problem gamblers in New Zealand. It is this population along with people who self identify to belonging to one or more Pacific nations, who spend the most on gambling. Māori and Pacific peoples currently lose money by way of gambling and this resource is used by different groups and redistributed by various bodies, to support community activities, (Ministry of Health 2007). Due to current anomalies in our gambling legislation, Māori do not have same rights as the Crown to be involved in the governance of such bodies as the New Zealand Lottery Grants Board which distributes funds from bi-weekly state run lotteries and other gambling products. Māori are also not involved in determining the governance of gambling machine distribution bodies and local governments. All of these bodies are involved in the advertising and promotion of gambling in local communities and determine the location of gambling venues.

Limited Māori representation means that Māori have minimum influence in directing where gambling losses are redistributed, which community groups are supported and therefore, which community structures and activities are actively developed and supported over time. This anomaly continues despite growing recognition that health status of individuals, ethnic groups and communities is linked to income and social deprivation. As a consequence of income and social deprivation low income communities generally experience poorer health than those who live in affluent areas. The depletion of resources from families has ongoing effects, it leads to increasing to social and economic decline. Just over $50 \%$ of the Māori population now live in low income communities and the poor health status of Māori is reflected in this situation (Ministry of Health 2009).

\section{Housework}

House work is used as a metaphor for this paper to discuss gambling public health action, which are activities and research undertaken to reduce gambling related harm. Housework are those activities occurring at home or surrounding community that people undertake to make their home and environment clean and safe and in the process undertake actions which enable defined values and beliefs to be transferred across generations. Many Māori are now involved in housework to make a difference in their personal lives, families, whānau and communities. They often do this task by way of employment through different agencies, representing or encouraging the Government, to provide and fund specific treatment and public health services as well as legislative and policy changes to reduce gambling harm in communities with the overall aim to improve the wellbeing of all in New Zealand. To undertake housework, Māori have recognised that you require specific skills, knowledge and have to be prepared to do it on a regular basis. To do tasks regularly often requires the development of rules or boundaries to be established such as completing tasks within a defined timeframe so that other important activities can occur. Once housework duties are completed those involved often feel a sense of satisfaction for they have achieved some degree of order and can see that a difference has been made. Housework nevertheless is never finished for just as you have completed duties a new mess is made by others and the cycle of tidying and cleaning begins again. Overall housework is an exhausting activity, it is 
generally not paid or rewarded well but is a requirement if individuals, families and communities are to function well. Doing housework has many similarities as public health, it is ongoing, results achieved are unnoticed and only recognised when it is not done and reaches a stage that it effects the wellbeing of all within a family, whānau or community opening up the environment to new health risks as influenza or crime epidemic.

\section{Public Health Approach to Gambling}

New Zealand has adopted a public health approach to address and eliminate the harms associated with problem gambling and has seen itself as a leader but has not been brave enough to eliminate gambling machines and casinos from most communities, unlike the situation in Russia (Eckle 2009). A public health approach to addressing problem gambling was negotiated and is incorporated in the Gambling Act 2003. This Act, defines the role and place of different gambling industries and allows for the development of harm minimisation requirements to promote responsible gambling and to reduce gambling related harm (Dyall and Manaia 2005). A number of harm minimisation regulations are now in place to ensure that those who operate gambling venues are good hosts and keep their places clean and safe as defined by the Crown (Dyall and Manaia 2005). When the Gambling Act 2003, was passed there was limited Māori involvement and the legislation was politically contentious (Dyall 2002). This tension continues today with different stakeholder groups requesting changes to be made to the legislation, for changes to occur at a local government level and improved operational policies to promote patron and public safety and to reduce crime associated with gambling, especially at casinos (Dyall 2003; Adams et al. 2010).

Throughout Māori engagement in the business of gambling, there has been constant advocacy for recognition and inclusion of the Treaty of Waitangi in gambling legislation and all policy matters, instead of being reliant on different statutes as the Local Government Act 2002 as lever for social change. This advice although acknowledged as important by key policy advisers has not been included to enable effective public health decisions to reduce gambling harm. This lack of clarity has meant that Māori have not been able to influence significantly the advice given by the Gambling Commission to the Government of the full extent of the compensation gambling providers should have to pay for the gambling harm they create. It also has affected the way the Department of Internal Affairs develops harm minimisation regulations, monitors and enforces the requirements of the Gambling Act 2003. Minimal consideration has been given to Māori and therefore indigenous views on how to address gambling related harm from our value system such as, using "powhiri", as a process which recognises that all responsible gambling hosts must be concerned about the safety of visitors to their venues, the effects their behaviours have on others whilst there and their need to return home safely back to the their families and communities (Dyall and Manaia 2005).

\section{Gambling Venue Policies}

Locally elected government are now required to review at least every 3 years there gambling venue policy. To undertake this statute direction, there is a requirement to consult widely with different community groups and a legal responsibility to seek the advice of Māori. This requirement places responsibility on local councils to inform Māori about the impact of gambling and associated harm in their communities and to give Māori resources to support their involvement and engagement throughout the process of decision making. Further, for 
Māori voices to be heard independently and at least equal to the other voices collectively in the community. In reality this does not occur Māori voices often are muffled and just included in the diversity of voices in the community as gambling issues are always politically contentious.

The political nature of gambling is visible when observing elected councillors whom are required when making decisions to determine the costs and benefits of restricting the growth of gambling machines and the flow on effects of more or less money available for local community groups and infrastructure. Reduction of gambling funding significantly impacts on funding for sports, cultural and community activities and despite Māori expenditure through gambling machines there is little investment in specific Māori activities. Gambling decisions made by councillors impact on how they are seen by different sections of a community, especially those who have personal conflicts of interest which are not declared such as being in a governance position operating a gambling machine trust, owning bars with gambling machines, or being part of a community group which receives gambling funds. Through public health action it has been found that councillors often do not declare their conflicts of interests in relation to gambling and only do so when publicly embarrassed requiring previous decisions to be revisited. Dishonesty creates more work for those involved in gambling public health action.

Overall Māori involvement in gambling public health requires endurance. Those involved have to know where all the dirt exists in their communities and decide how to expose and where possible remove. This often occurs by focusing on those who are hurt by gambling and encouraging them to speak out regarding the effects on their children, elders and the ongoing health impacts for those with co morbidity health problems which often lead to mental health issues and imprisonment. Decisions made today and intergenerational effects across generations are generally ignored when key gambling policy decisions are made by local governments. Keeping local councillors and local governments honest in their role and function is exhausting work for Māori as the indigenous population is always placed in a position of conflict. For effective public health action there is always a threat of marginalisation and the possible loss of contract and scapegoating those involved suggesting they have not been professional in their role (Dyall 2010b). Tension and conflict is the process in which change slowly occurs.

\section{Gambling Treatment Services}

Māori are involved in the provision of gambling treatment services. Those involved are required to promote and encourage those affected by gambling related harm to seek help. For many who have gambling issues they only seek help when in real crisis, such as, a threat to the break up of their family, rising financial debt, loss of job or having to face a criminal offence (Dyall 2010b). Services are planned and funded on the basis of those who present help and ignores those population groups which are vulnerable, find it difficult to seek help or there are barriers in place which restrict access to gambling treatment services. Māori subpopulations which have been identified as having special needs to be met in relation to gambling are: children and youth, people with co-morbidities, women and elders (Dyall and Hand 2003; Dyall 2007). Whānau oriented services are now needed, for often within an extended family there are several family members with gambling problems (Dyall 2010a, b). Their behaviour then affects others, causing further health, social, justice issues within that family system. Māori now advocate that their indigenous values, aspirations and human rights should now be included in the development of any gambling policies and gambling related services in New Zealand. 


\section{Indigenous Imprisonment}

One in three recently imprisoned males and females prisoners have been identified within the last 6 months that they had problems with gambling and this is linked to their pattern of offending (Abbott and McKenna 2000; Abbott et al. 2000a) Māori at any time make up 50\% of prisoners and it is expected that imprisonment will increase due to the youthfulness of the Māori population. Further the increasing degree of alcohol, substance abuse and problem gambling in communities and increasing social and health inequalities is contributing to increased imprisonment. New prisons are now being planned to be built to accommodate the projected increase of imprisonment. In contrast to this projection, THWOTOW has advocated that new diversion options for offenders, especially in relation to gambling should be established in communities. This is to ensure individuals are accountable for their offences in their communities in an appropriate way allowing for restorative justice and for their future life course not to be jeopardised with a formal criminal record (Te Herenga Waka O Te Ora Whanau 2004).

Two thirds of female prisoners in New Zealand are Māori and this population group is expected to grow. More Māori women then Māori men now present for help with problems related to gambling machines (Ministry of Health 2008a, b). To respond positively to Māori women needs and involvement in gambling, new recreational opportunities need to be created in communities which are safe for women, strengthen their identity, build whānaungatanga or family connections and which strengthen communities (Morrison 2004). Healthy communities are those which have strong families and have few people with addictions (Dyall 2010a, b).

\section{Public Health Action}

Involvement in gambling public health action requires considerable energy. Those involved have to identify what degree of awareness communities have regarding gambling and harm and are required to work with communities to develop appropriate solutions to reduce harm. To make a difference individuals and organisations are encouraged to make submissions to their local council or write to members of Parliament asking such questions who really benefits from gambling and why are gambling machines concentrated in low income communities with minimum community support. Empowering communities also requires gambling public health advocates to become involved in community based research and then supporting community groups to develop health warning messages and find new ways to inform communities of the dangers associated with gambling. All of these tasks require public health workers to be resilient and to have stamina for the political and social context of their work is dynamic and ever changing.

Taking a time out, often only occurs when there is a requirement for a gambling audit or review. This gives gambling public health advocates the space to reflect and to investigate what difference has been achieved. Due to normalisation of gambling within communities and limited Māori involvement in decision making on gambling, it is often difficult to assess and identify changes that have occurred, which are visible and can be measured, such as, the number community groups deciding not to apply or take gambling funding to support their activities, even though this will make their work harder and they may not survive financially. Involvement in the community by gambling public health advocates also supports recruitment of new people to become involved either on a paid or unpaid basis to be actively involved in the transfer of knowledge, such as convening and organising community events, hui on marae, and engagement in local, national and international conferences. All of these activities strengthen alliances and knowledge transfer. 


\section{Gambling Research}

Involvement in gambling public health includes research as increased knowledge supports ongoing advocacy and helps identify where increased housework needs to be undertaken. Researchers and gambling health advocates now often work together. Over the years it has been learnt that researchers and advocates cannot work in isolation from each other, nor separate from communities so as to enable the development of appropriate research questions and research methodologies which are appropriate and include recognition of matters of tikanga Māori. Ethics associated with gambling research is often contentious as it requires considerable discussion as to whom is an appropriate funder of research, such as the Ministry of Health, and therefore, what degree of control or influence will there be in directing or interpreting the findings of the research. To resolve this dilemma an arm's distance relationship has been established with the Gambling Commission providing advice to the Government every 3 years of the levy required to be paid by specific gambling industries to compensate for the harm created by different forms of gambling. The full cost of damage to Māori and Pacific communities is generally unrecognised and therefore, funding is always limited for these communities. The Government who is the major benefactor of gambling, determines the funding the Ministry of Health allocates for interventions and research to reduce gambling harm. Communities interest in gambling research until recently has been ignored by the Ministry of Health and thus they have been reliant on researchers to provide information or to pilot or test new interventions.

For Māori independent research funding is critical, for without independence from the Crown, Māori as tangata whenua cannot perform their Treaty of Waitangi responsibility in acting as kaitiaki or protector of those living in different communities and for the country. This role has become more important with new immigrants choosing to live in New Zealand now exposed to wide scale gambling and due to their socio economic situation are vulnerable to gambling related harm.

Research in New Zealand has identified that those who live within $5 \mathrm{~km}$ of gambling machines are at risk of gambling harm. Venues have been strategically positioned in low income communities and this now affects many directly and indirectly all those who live in these communities. Gambling research has also identified that for those with gambling problems, this affects all domains of their wellbeing: physically, mentally, spiritually and the wellbeing of their family (Casswell et al. 2008; Ministry of Health 2008a, b). Those intimately associated with those with gambling problems generally have a similar health status profile as the problem gambler.

\section{Duty of Care Responsibilities}

Having gained an appreciation of the complexities of undertaking housework on a regular basis, Māori have now moved their focus on to duty of care responsbilities, a requirement that gambling licensing and monitoring organisations are required to undertake on a daily basis in accordance with statute and licensing requirements. Māori have realised it is difficult to keep your house or community clean when the locus of control exists elsewhere. Those in senior gambling decision and monitoring licensing positions are now required to stand tall and to protect not only gamblers but also those who are vulnerable to the effects of gambling harm and often not visible in venues but are at home, such as children, those who are sick and frail elders. The full intergenerational effects of gambling related harm is now being recognised and solutions to address are now being considered, 
such as Whānau Ora, a new policy to rebuild and strengthen extended families, (Durie 2010). Decisions to reduce gambling related harm are not easy, they are always politically contentious and those who speak out from a public health perspective are often victimised in some way.

Māori are now exercising their right to approach the Waitangi Tribunal, an independent judicial body, which is charged with the responsibility to hear any claims where Māori individually or collectively consider that that there has been a breach of Treaty of Waitangi rights and thus indigenous human rights. A claim has been registered by Ms Ruth Herd for the Waitangi Tribunal, number 1909, to consider the effects of gambling machines in communities and Treaty of Waitangi implications. The claim, when heard will provide a new opportunity for Māori and nonMāori in a new forum with tribunal members, presenting information on the harm that gambling has created for Māori and the wider community. Utilisation of legal pathways for public health action is not radical, but is one of the tools that can be used to create social, economic and cultural changes at a local, national level and may move to an international level.

\section{Conclusion}

Housework is a time consuming activity which is often done by a few for the good of many and generally not appreciated until no activity occurs. Māori have been involved in gambling public action for a decade or more. Through this process Māori have developed and lead an indigenous gambling perspective and with the aim where possible to reduce and remove gambling related harm from our communities. To achieve this task Māori have established their own voice through THWOTOW and have aimed to work with different organisations and groups at a local, national and international level to reduce gambling related harm. Being involved in gambling public health is consistent with the Gambling Act 2003 and New Zealand's founding constitutional document the Treaty of Waitangi rights and now United Nations Declaration on the Rights of Indigenous Peoples.

Ehara taku toa i te toa takitahi

Engari he toa takitini

My strength is not that of the individual

But that of the multitudes

\section{References}

Abbott, M., \& McKenna, B. (2000). Gambling and problem gambling among recently sentenced Women prisoners in New Zealand Report Number Four of the New Zealand Gaming Survey. Wellington: Department of Internal Affairs.

Abbott, M., \& Volberg, R. (1991). Gaming and problem gambling in New Zealand research Series No 12. Wellington: Department of Internal Affairs.

Abbott, M., McKenna, B., et al. (2000). Gambling and problem gambling among recently sentenced males in four New Zealand prisons. Wellington: Department of Internal Affairs.

Adams, P., Buetow, S., \& Rossen, F. (2010). Vested Interests in Addiction Research and Policy Poisonous partnerships: Health sector buy-in to arrangements with government and addictive consumption industries. Addiction, 105, 585-590.

Australian Institute for Gambling Research. (1998). Study of the social and economic impacts of New Zealand casinos. Auckland: Casino Control Authority. 
Casswell, S. et al. (2008). Assessment of the Impacts of Gambling in New Zealand, Centre for Social and Health Outcomes Research and Evaluation \& Te Ropu Whariki http://www.shore.ac.nz/projects/Gambling_impacts (1June 2010).

Department of Internal Affairs. (1996). Gaming- A new direction for New Zealand Department of Internal Affairs policy options. Wellington: Department of Internal Affairs.

Durie, M. (2001). Mauri Ora the dynamics of Maori Health. Auckland: Oxford University Press.

Durie, P. (2010). Whanau Ora: Report on the Taskforce on Whanau-Centred Initiatives, to the Hon. Wellington: Tariana Turia Minister for the Community and Voluntary Sector.

Dyall, L. (2002). Kanohi ki te kanohi: Face to face A Maori face to gambling. New Ethicals Journal: New Zealand's Journal of Patient Management, 5(1), 11-16.

Dyall, L. (2003). Kanohi ki te Kanohi A Maori Face to Gambling. University of Auckland.

Dyall, L. (2004). Gambling: A social hazard. Social Policy Journal of New Zealand/Te Puna Whakaaro, $\operatorname{March}(21), 22-40$.

Dyall, L. (2006). Gambling, social disorganisation, and deprivation. Wellington: International Conference on Gambling.

Dyall, L. (2007). Gambling, Social disorganisation and deprivation. International Journal of Mental Health and Addiction (5), 320-330.

Dyall, L. (2009). Spring : A Time to Celebrate. Inaugural Maori Gambing Health Awards: Sowing the Seeds for Whanau Development. Sorrento, Epsom, Auckland. (unpublished)

Dyall, L. (2010a). Gambling: A Poison Chalice for Indigenous Peoples'. International Journal of Mental Health and Addiction (8), 205-213.

Dyall, L. (2010b). Gambling and Whanau Ora: Changing Lifestyles and Life choices. He Pukenga Körero, 9 (Summer), 35-43.

Dyall, L., \& Hand, J. (2003). Maori and Gambling :Why a comprehensive Maori public health response is required in Aotearoa. Ecommunity International Journal of Mental Health \& Addiction, 1(1), 1-16.

Dyall, L., \& W. Manaia (2005). Powhiri and the Treaty of Waitangi: A Maori protocol framework for host responsibility. Ecommunity International Journal of Mental Health \& Addiction (Proceedings of the New Zealand International Gambling Conference): 8-14.

Dyall, L., \& Morrison, L. (2002). Maori, the Treaty of Waitangi and gambling. Gambling in New Zealand. B. Curtis. Palmerston North: Dunmore Press.

Eckle, M. (2009). Russia takes a gamble with remote casinos. htt:/www.theeagle.com/business/Russia- takesa- gamble- with remote-casinos 31 July 2009.

Human Rights Commission (2008). United Nations Declaration on the Rights of Indigenous Peoples, Human Rights Commission http://www.hrc.co.nz.

Marmot, M. (2010). Fair Society, Heathly Lives The Marmot Review Executive Summary Strategy Review of Health Inequalities in England post 2010. UCL.

Ministry of Health (2007). Problem Gambling Intervention Services in New Zealand 2006 Service- user statistics. P. H. I. M. R. No.14. Wellington.

Ministry of Health (2008a). Problem Gambling Intervention Services in New Zealand 2007 Service- user staistics. Wellington, Public Helath Intelligence Monitoring Report No. 18f.

Ministry of Health (2008b). Raising the Odds? Gambling behaviour and neighbourhood access to gambling venues in New Zealand. Wellington, Public Helath Intelligence Occassional Bulletin.No 47.

Ministry of Health (2009). Preventing and Minimising Gambling Harm 2010-2016- Report to the Commissioners Post Consultation September 2009. Wellington Ministry of Health.

Morrison, L. (2004). Pokie Gambling and Maori Women: Friend or foe? Journal of Gambling Issues, 12, 120.

Te Herenga Waka O Te Ora Whanau (2004). He Huarahi Whiringa:An Alternative Way, Te Herenga Waka O Te Ora Whanau. 